\title{
A new genus of the order Actinomycetales, Cryptosporangium gen. nov., with descriptions of Cryptosporangium arvum sp. nov. and Cryptosporangium japonicum sp. nov.
}

\author{
Tomohiko Tamura,' Masayuki Hayakawa² and Kazunori Hatano'
}

Author for correspondence: Tomohiko Tamura. Tel: +8163006555 . Fax: +8163006814 . e-mail: k90089@simail.ne.jp

\footnotetext{
1 Institute for Fermentation, Osaka, 2-17-85 Jusohonmachi Yodogawa-ku, Osaka 532, Japan

2 Department of Applied Chemistry and Biotechnology, Faculty of Engineering, Yamanashi University, 4-3-11 Takeda, Kofu, Yamanashi 400, Japan
}

\begin{abstract}
Four strains that form sporangia with motile sporangiospores and mycelia were isolated from soil samples. Their many sporangia were covered by mycelia. They had glutamic acid, glycine, alanine and meso-diaminopimelic acid as cell wall amino acids (wall chemotype II), acofriose (3-Omethylrhamnose) as a characteristic whole-cell sugar, and menaquinone $\mathbf{9}\left(\mathrm{H}_{6}\right)$. The taxonomic characteristics of these strains differ from those of the previously described motile actinomycetes. On the basis of the morphological, physiological, chemotaxonomic and phylogenetic analyses, a new genus is proposed, Cryptosporangium, and two new species, Cryptosporangium arvum sp. nov. (type strain IFO 15965') for strain YU 629-21 ${ }^{\top}$ and Cryptosporangium japonicum sp. nov. (type strain IFO 15966') for strains YU 636-3', YU 655-31 and YU 656-31.
\end{abstract}

Keywords: Cryptosporangium gen. nov., Cryptosporangium arvum sp. nov., Cryptosporangium japonicum sp. nov., suborder Frankineae, 16S rRNA

\section{INTRODUCTION}

Phylogenetic studies on the basis of 16S rRNA sequences are useful in the classification of actinomycetes. Recently, Stackebrandt et al. (1997) suggested reclassification at the family level of actinomycetes on the basis of the 16S rRNA sequences phylogenetic clustering and the presence of taxon-specific $16 \mathrm{~S}$ rRNA/DNA signature nucleotides. According to their reclassification (Stackebrandt et al., 1997), actinomycetes with motile sporangiospores belong to the families Streptosporangiaceae [Planomonospora (Thiemann et al., 1967a), Planobispora (Thiemann \& Beretta, 1968) and Planotetraspora (Runmao et al., 1993)], Micromonosporaceae [Actinoplanes (Couch, 1950), Dactylosporangium (Thiemann et al., 1967b) and Pilimelia (Kane, 1966)], Pseudonocardiaceae [Streptoalloteichus (Tomita et al., 1978)], Thermomonosporaceae [Spirillospora (Couch, 1963)], Dermatophilaceae [Dermatophilus (Gordon, 1964)] and Geodermatophilaceae [Geodermatophilus (Luedemann, 1968)].

The GenBank/EMBLDDBJ accession numbers for the sequences in this paper are listed in Table 1.
During our taxonomic studies of motile actinomycetes isolated from natural sources, we isolated four strains, YU 629-21 ${ }^{\mathrm{T}}$, YU 636-3 ${ }^{\mathrm{T}}$, YU 655-31 and YU 656-31, which produced round and irregularly shaped sporangia and mycelia. In studying the taxonomic position of the four strains, we found that they are motilesporangiospore-bearing actinomycetes that contain menaquinone $9\left(\mathrm{H}_{6}\right)$ [MK-9 $\left.\left(\mathrm{H}_{6}\right)\right]$ and have meso-diaminopimelic acid and glycine in their cell walls (wall chemotype II). The members of the family Micromonosporaceae, except for the genera Couchioplanes (Tamura et al., 1994) and Catenuloplanes (Yokota et al., 1993), and the genus Glycomyces (Labeda et al., $1985)$ are known to have chemotype II. However, the isolates differ from previously described actinomycetes in various characteristics.

In this paper, we describe the characterization and classification of strains YU 629-21 ${ }^{\mathrm{T}}$, YU 636-3 ${ }^{\mathrm{T}}$, YU 655-31 and YU 656-31, and propose that these organisms should be included in a new genus, Cryptosporangium, as members of Cryptosporangium arvum sp. nov. for $\mathrm{YU} 629-21^{\mathrm{T}}$ and Cryptosporangium japonicum sp. nov. for YU 636-3 ${ }^{\mathrm{T}}$, YU 655-31 and YU 656-31. 


\section{METHODS}

Micro-organisms and culture conditions. The isolates are listed in Table 1. Strains YU 629-21 ${ }^{\mathrm{T}}$, YU 636-3 ${ }^{\mathrm{T}}$, YU 65531 and YU 656-31 were isolated from soil samples collected at Kofu, Yamanashi, and Miyako Island, Okinawa Prefecture, Japan, on humic acid/vitamin (HV) agar (Hayakawa \& Nonomura, 1987) using the capillary method (Hayakawa et al., 1992). To obtain freeze-dried mass for chemotaxonomic analyses, the isolates were grown at $28^{\circ} \mathrm{C}$ for $5 \mathrm{~d}$ in yeast extract/glucose broth (containing $10 \mathrm{~g}$ yeast extract and $10 \mathrm{~g} \mathrm{D}$-glucose in $1000 \mathrm{ml}$ distilled water, $\mathrm{pH} 7 \cdot 0$ ) on a rotary shaker.
Cultural characteristics were recorded after $14 \mathrm{~d}$ incubation at $28{ }^{\circ} \mathrm{C}$ according to the International Streptomyces Project (ISP) method (Shirling \& Gottlieb, 1966). Colours are described in common terminology, but exact colours were determined by comparison with colour chips of the $\mathrm{My}$ cological Colour Chart (Rayner, 1970).

Morphological and physiological characteristics. Morphological features were observed on HV agar, and physiological features were observed on media by the methods of Shirling \& Gottlieb (1966). Motility was observed with a light microscope using culture grown on HV agar for $7-10 \mathrm{~d}$ at $28^{\circ} \mathrm{C}$, then incubated at $28^{\circ} \mathrm{C}$ for $1 \mathrm{~h}$ in $0.01 \mathrm{M}$ phosphate

Table 1. Strains investigated in this study and accession numbers for 165 rRNA sequences

\begin{tabular}{|lcc|}
\hline Strain & Source & $\begin{array}{c}\text { Accession } \\
\text { no. }\end{array}$ \\
\hline YU 629-21 $1^{\mathrm{T}}\left(=\right.$ IFO $\left.15965^{\mathrm{T}}\right)$ & $\begin{array}{c}\text { Soil from a vegetable field in } \\
\text { Yamanashi Prefecture, Japan } \\
\text { YU 636-3 }\end{array}$ & D85465 \\
YU 655-31 & $\begin{array}{c}\text { Soil from a sugar cane field in } \\
\text { Okinawa Prefecture, Japan }\end{array}$ & D85466 \\
YU 656-31 & $\begin{array}{c}\text { Soil from a vegetable field in } \\
\text { Yamanashi Prefecture, Japan }\end{array}$ & AB006168 \\
& $\begin{array}{c}\text { Soil from a vegetable field in } \\
\text { Yamanashi Prefecture, Japan }\end{array}$ & AB006166 \\
\hline
\end{tabular}
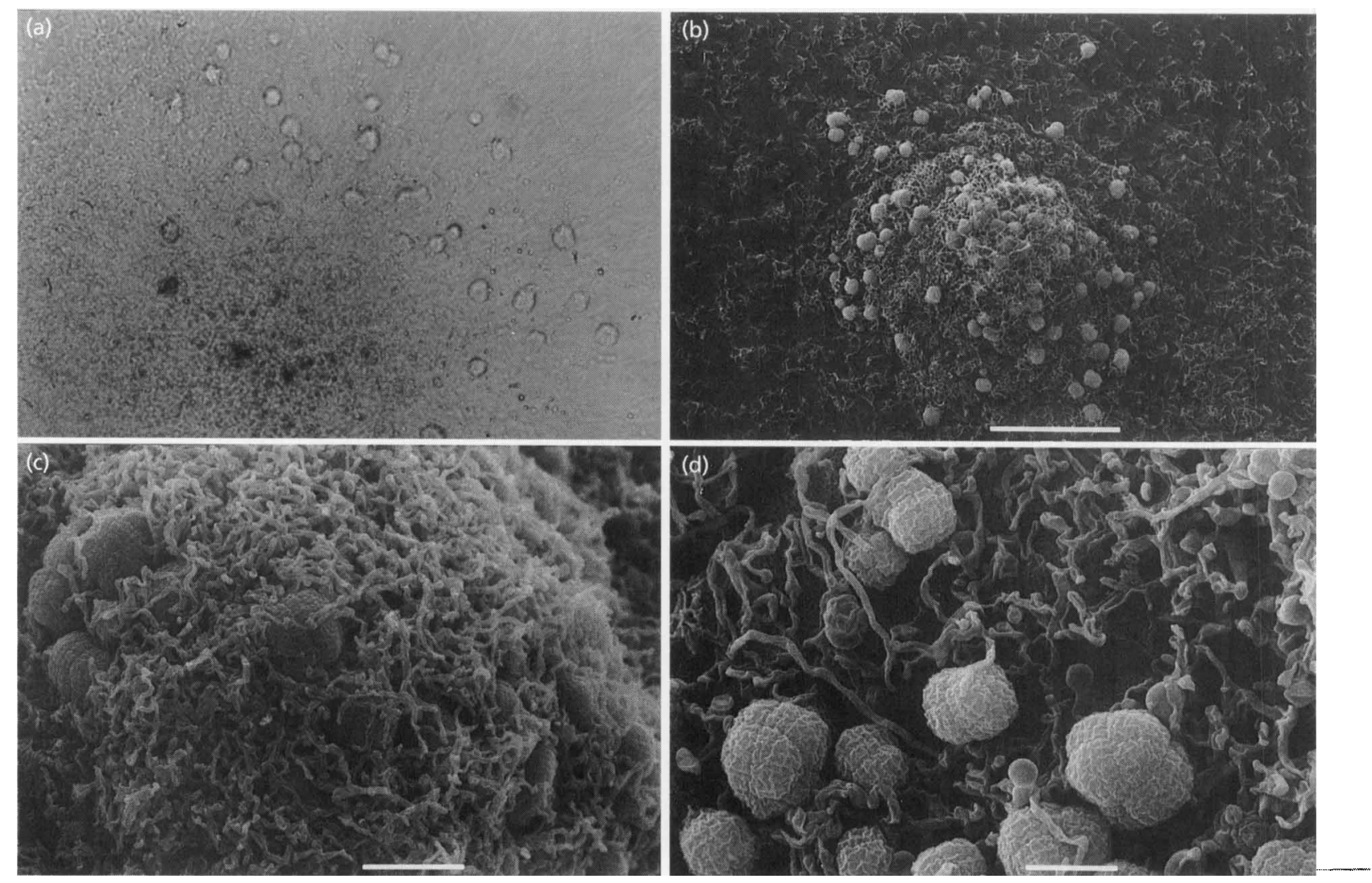

Fig. 1. Light micrograph (a) and scanning electron micrographs (b-d) of isolate $\mathrm{YU} 629-21^{\top}$ grown on $\mathrm{HV}$ agar for $14 \mathrm{~d}$ at $28^{\circ} \mathrm{C}$. Bars, $50 \mu \mathrm{m}$ (b), $10 \mu \mathrm{m}$ (c) and $5 \mu \mathrm{m}$ (d). 

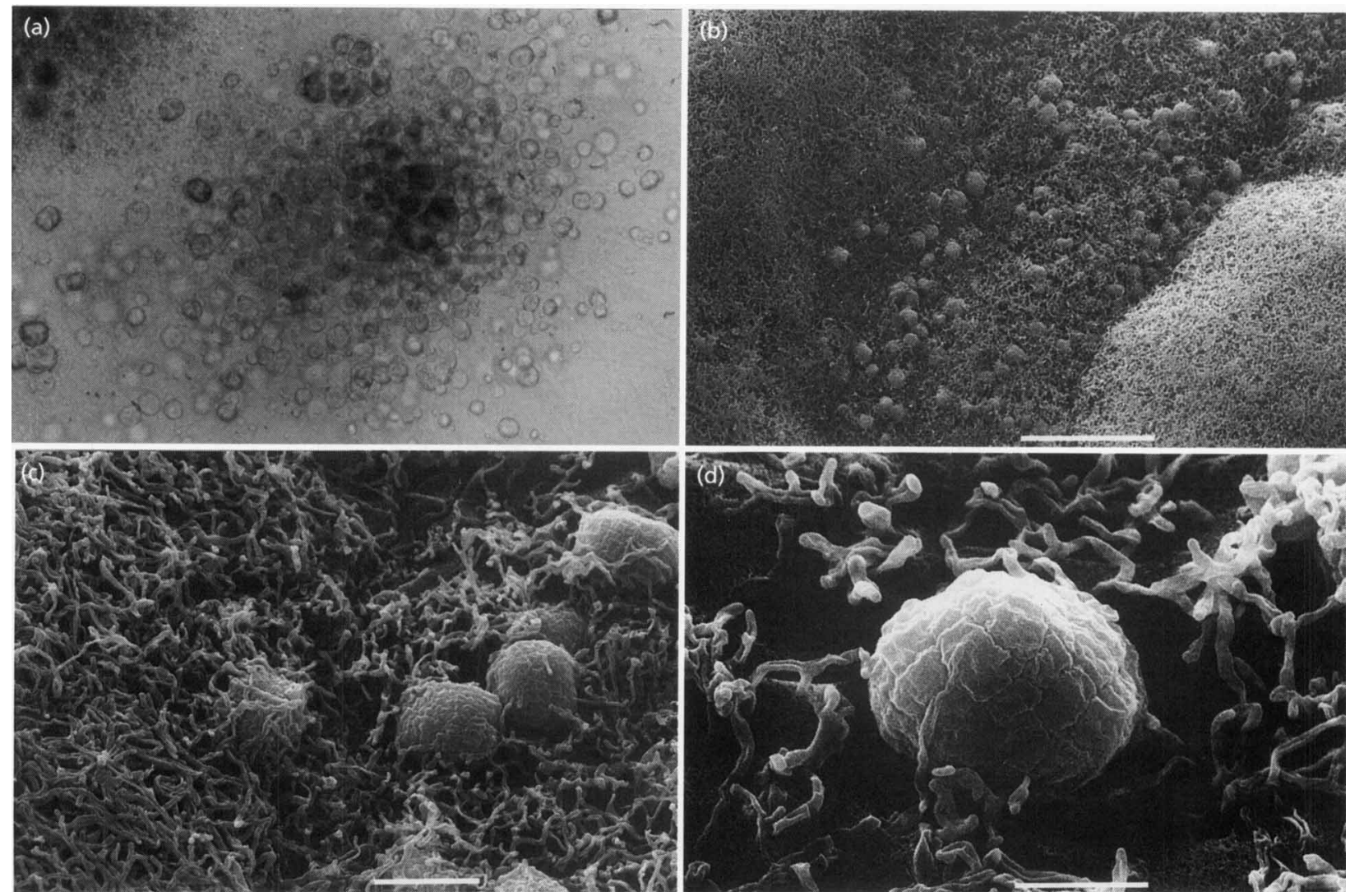

Fig. 2. Light micrograph (a) and scanning electron micrographs (b-d) of isolate $\mathrm{YU} 636-3^{\top}$ grown on $\mathrm{HV}$ agar for $14 \mathrm{~d}$ at $28^{\circ} \mathrm{C}$. Bars, $50 \mu \mathrm{m}$ (b), $10 \mu \mathrm{m}$ (c) and $5 \mu \mathrm{m}$ (d).

buffer (pH 7.0) containing $10 \%$ soil extract. Culture grown on HV agar for $14 \mathrm{~d}$ at $28^{\circ} \mathrm{C}$ was observed with a scanning electron microscope (model JSM-5400; JEOL). Samples for scanning electron microscopy were prepared by cutting a block of agar with growth of the strain, fixing the block in osmium tetroxide vapour at room temperature for $4 \mathrm{~h}$, dehydrating cells through a graded ethanol series followed by critical point drying (model HCP-2; Hitachi Koki), then sputter coating the preparation with palladium under vacuum.

Analyses of chemotaxonomic characteristics. Analyses of whole-cell sugars, polar lipids, cellular fatty acids, mycolic acids, isoprenoid quinones and amino acid composition of the cell walls and the glycolate test were performed as described previously (Tamura et al., 1994).

DNA base composition. DNA was obtained by the method of Saito \& Miura (1963). The G+C content of the DNA was determined by the method of Mesbah et al. (1989) after treatment with $\mathbf{P} 1$ nuclease and alkaline phosphatase and by HPLC, using a model LC-6AD apparatus (Shimadzu) equipped with a Cosmosil $5 \mathrm{C}_{18}$-AR column $(4.6 \times 150 \mathrm{~mm}$; Nacalai Tesque).

DNA homology experiment. DNA-DNA homology was studied using the photobiotin microplate hybridization method of Ezaki et al. (1989).

PCR amplification and sequencing of 16S rDNA. 16S rRNA was amplified by PCR (Saiki et al., 1988) using TaKaRa Taq (Takara Shuzo) and a pair of primers, 9F (5'-GAGTTTG-
ATCCTGGCTCAG) and 1541R (5'-AAGGAGGTGATCCAACC). The conditions for thermal cycling were denaturation of the target DNA at $96^{\circ} \mathrm{C}$ for 2 min followed by 30 cycles of denaturation at $95^{\circ} \mathrm{C}$ for $1 \mathrm{~min}$, primer annealing at $55^{\circ} \mathrm{C}$ for $1 \mathrm{~min}$ and primer extension at $72{ }^{\circ} \mathrm{C}$ for $2 \mathrm{~min}$. At the end of cycling, the reaction mixture was held at $72^{\circ} \mathrm{C}$ for $5 \mathrm{~min}$, then cooled to $4^{\circ} \mathrm{C}$.

The $1.5 \mathrm{~kb}$ amplified $16 \mathrm{~S}$ rDNA was subjected to cycle sequencing by using a Thermo Sequenase fluorescently labelled primer cycle sequencing kit with 7-deaza dGTP (Amersham) according to the manufacturer's protocol with the following primers: 5'-CTCCTACGGGAGGCAGCAG-3' (339F), 5'-GTATTACCGCGGCTGCTG-3' (536R), 5'-GCAACGAGCGCAACCC-3' (1099F) and 5'-GCGGTGTGTACAAGGCCC-3' (1382R). The conditions for thermal cycling were denaturation of the target DNA at $95^{\circ} \mathrm{C}$ for $5 \mathrm{~min}$ followed by 30 cycles of denaturation at $95^{\circ} \mathrm{C}$ for $0.5 \mathrm{~min}$, primer annealing at $55^{\circ} \mathrm{C}$ for $0.5 \mathrm{~min}$ and primer extension at $72{ }^{\circ} \mathrm{C}$ for $1 \mathrm{~min}$. The products were analysed with a Pharmacia ALF DNA Sequencer II according to the manufacturer's protocol.

Phylogenetic analysis. 16S rRNA sequences of the strains examined and reference organisms were aligned against that of Streptomyces ambofaciens (Pernodet et al., 1989). The sequences were aligned with published sequences from DDBJ, GenBank and EMBL by the $K_{\text {nue }}$ value of Kimura (1980), and the phylogenetic tree was constructed by the neighbour-joining method (Saitou \& Nei, 1987) from $K_{\text {nuc }}$ values. The topology of the phylogenetic tree was evaluated 
by the bootstrap resampling method of Felsenstein (1985) with 1000 replicấtes.

\section{RESULTS}

\section{Morphological observations}

Morphological observation of the 14-d-old cultures of isolates grown on $\mathrm{HV}$ agar revealed the presence of round or irregularly shaped sporangia and mycelia. Some sporangia, especially on the central part of the colony, were submerged under thick mycelia (Figs $1 \mathrm{~b}$, $c$ and $2 b, c)$, making them difficult to observe by light microscopy (Figs la and 2a). In strain YU 629-21 ${ }^{\mathrm{T}}$, many swollen structures resembling globose bodies or immature sporangia were observed on the mycelium (Fig. 1a, d). Sporangia were $3-10 \mu \mathrm{m}$ in diameter.

After incubation at $28^{\circ} \mathrm{C}$ for $1 \mathrm{~h}$ in water or $0.01 \mathrm{M}$ phosphate buffer ( $\mathrm{pH} \mathrm{7.0)} \mathrm{containing} 10 \%$ soil extract, many spores showed motility.

\section{Growth characteristics}

As shown in Table 2, isolates developed yellow to orange colonies on most media tested. Isolates showed good growth on yeast extract/malt extract agar (ISP medium 2), and produced greyish reddish orange soluble pigment on tyrosine agar (ISP medium 7). Isolates developed sporangia on inorganic salts/starch agar (ISP medium 4), glycerol/asparagine agar (ISP medium 5), tyrosine agar (ISP medium 7), nutrient agar and HV agar.

\section{Physiological and biochemical characteristics}

The biochemical properties of isolates are shown in Table 3. All isolates utilized D-glucose, inositol, raffinose, saccharose, D-mannitol, L-rhamnose, D-xylose, L-arabinose, lactose, maltose and D-mannose. Strains YU $629-21^{\mathrm{T}}$ and YU 636-3 ${ }^{\mathrm{T}}$ did not utilize D-sorbitol, but strains YU 655-31 and YU 656-31 did utilize it. Only strain YU $629-21^{\mathrm{T}}$ did not utilize D-fructose. The

Table 2. Cultural characteristics of the strains studied

The colour codes in parentheses correspond to those in the Mycological Colour Chart (Rayner, 1970).

\begin{tabular}{|c|c|c|c|c|}
\hline \multirow[t]{2}{*}{ Medium } & \multicolumn{4}{|c|}{ Description of growth, and colour of colony for strain: } \\
\hline & YU 629-21 ${ }^{\mathrm{T}}$ & YU 636-3 & YU 655-31 & YU 656-31 \\
\hline \multirow[t]{2}{*}{ ISP medium 2} & Good & Good & Good & Good \\
\hline & $\begin{array}{l}\text { Strong orange }(7) \text { to } \\
\text { light to moderate } \\
\text { orange-yellow }(10)\end{array}$ & $\begin{array}{l}\text { Light to moderate } \\
\text { orange-yellow (10) }\end{array}$ & $\begin{array}{l}\text { Strong orange (7) to } \\
\text { light to moderate } \\
\text { orange-yellow (10) }\end{array}$ & $\begin{array}{l}\text { Strong orange }(7) \text { to } \\
\text { light to moderate } \\
\text { orange-yellow (10) }\end{array}$ \\
\hline \multirow[t]{2}{*}{ ISP medium 3} & Poor & Poor & Poor & Poor \\
\hline & $\begin{array}{l}\text { Light to moderate } \\
\text { orange-yellow (10) }\end{array}$ & $\begin{array}{l}\text { Moderate yellowish pink } \\
\text { (41) }\end{array}$ & $\begin{array}{l}\text { Light to moderate } \\
\text { orange-yellow (10) }\end{array}$ & $\begin{array}{l}\text { Light to moderate } \\
\text { orange-yellow (10) }\end{array}$ \\
\hline \multirow[t]{2}{*}{ ISP medium 4} & None & Poor & None & None \\
\hline & Light yellow (11) & $\begin{array}{l}\text { Moderate yellowish pink } \\
\text { (41) }\end{array}$ & Light yellow (11) & Light yellow (11) \\
\hline \multirow[t]{2}{*}{ ISP medium 5} & Moderate & Moderate & Poor & Poor \\
\hline & $\begin{array}{l}\text { Moderate orange-yellow } \\
\text { (44) to light to } \\
\text { moderate } \\
\text { orange-yellow }(10)\end{array}$ & $\begin{array}{l}\text { Light to moderate } \\
\text { orange-yellow (10) to } \\
\text { light yellow (11) }\end{array}$ & & Light yellow (11) \\
\hline \multirow[t]{2}{*}{ ISP medium 6} & Poor & Poor & Poor & Poor \\
\hline & $\begin{array}{l}\text { Moderate orange-yellow } \\
\text { (44) }\end{array}$ & $\begin{array}{l}\text { Moderate orange-yellow } \\
\text { (44) }\end{array}$ & $\begin{array}{l}\text { Moderate orange-yellow } \\
\text { (44) }\end{array}$ & $\begin{array}{l}\text { Moderate orange-yellow } \\
\text { (44) }\end{array}$ \\
\hline \multirow[t]{2}{*}{ ISP medium 7} & Poor & Poor & Poor & Poor \\
\hline & $\begin{array}{l}\text { Dark greenish yellow } \\
(40) \text { to strong brown }(9)\end{array}$ & $\begin{array}{l}\text { Strong brown (9) to light } \\
\text { greyish brown (106) }\end{array}$ & $\begin{array}{l}\text { Dark greenish yellow } \\
(40) \text { to strong brown (9) }\end{array}$ & $\begin{array}{l}\text { Dark greenish yellow } \\
(40) \text { to strong brown }(9)\end{array}$ \\
\hline \multirow[t]{2}{*}{ Nutrient agar } & Poor & Poor & Poor & Moderate \\
\hline & Pale yellow (45) & Pale yellow (45) & $\begin{array}{l}\text { Light yellowish brown } \\
(86)\end{array}$ & $\begin{array}{l}\text { Moderate orange-yellow } \\
\text { (44) }\end{array}$ \\
\hline \multirow{2}{*}{$\begin{array}{l}\text { Brain Heart } \\
\text { Infusion (Difco) }\end{array}$} & & Good & & \\
\hline & & $\begin{array}{l}\text { Moderate orange-yellow } \\
\text { (44) }\end{array}$ & & \\
\hline
\end{tabular}


Table 3. Phenotypic characteristics of the strains studied

++ , Good; + , moderate; \pm , poor;,- none.

\begin{tabular}{|c|c|c|c|c|}
\hline \multirow[t]{2}{*}{ Characteristic } & \multicolumn{4}{|c|}{ Strain } \\
\hline & YU 629-21 ${ }^{\mathrm{T}}$ & YU $636-3^{T}$ & YU 655-31 & YU 656-31 \\
\hline \multicolumn{5}{|l|}{ Utilization of: } \\
\hline Glucose & ++ & ++ & ++ & ++ \\
\hline Inositol & ++ & ++ & ++ & ++ \\
\hline Raffinose & $+t$ & ++ & ++ & ++ \\
\hline Saccharose & ++ & ++ & ++ & ++ \\
\hline D-Fructose & - & ++ & + & + \\
\hline D-Mannitol & ++ & ++ & ++ & ++ \\
\hline L-Rhamnose & + & + & + & + \\
\hline D-Xylose & ++ & ++ & ++ & + \\
\hline L-Arabinose & + & + & + & + \\
\hline Glycerol & + & \pm & + & + \\
\hline Lactose & ++ & $+t$ & ++ & ++ \\
\hline D-Galactose & \pm & ++ & + & ++ \\
\hline Maltose & ++ & ++ & ++ & ++ \\
\hline D-Mannose & $+t$ & ++ & ++ & ++ \\
\hline D-Sorbitol & - & - & $+t$ & ++ \\
\hline Inulin & - & - & - & - \\
\hline \multicolumn{5}{|l|}{ Growth on $\mathrm{NaCl}(\%)$ : } \\
\hline 0 & ++ & ++ & ++ & ++ \\
\hline 4 & - & - & - & + \\
\hline 7 & - & - & - & - \\
\hline Calcium malate hydrolysis & + & + & + & + \\
\hline Starch hydrolysis & - & - & - & - \\
\hline Nitrite from nitrate & - & - & - & - \\
\hline Peptonization of milk & + & + & + & + \\
\hline Gelatin liquefaction & - & - & - & - \\
\hline \multicolumn{5}{|l|}{ Pigmentation in: } \\
\hline ISP-1 & - & - & - & - \\
\hline ISP-6 & - & - & - & - \\
\hline ISP-7 & $\begin{array}{c}+, \text { Greyish reddish } \\
\text { orange }\end{array}$ & $\begin{array}{c}+, \text { Greyish reddish } \\
\text { orange }\end{array}$ & $\begin{array}{c}+, \text { Greyish reddish } \\
\text { orange }\end{array}$ & $\begin{array}{c}+, \text { Greyish reddish } \\
\text { orange }\end{array}$ \\
\hline \multicolumn{5}{|l|}{ Growth at $\left({ }^{\circ} \mathrm{C}\right)$ : } \\
\hline 10 & - & - & - & - \\
\hline 15 & ++ & + & ++ & ++ \\
\hline 20 & ++ & ++ & ++ & ++ \\
\hline 25 & ++ & ++ & ++ & ++ \\
\hline 30 & + & + & ++ & ++ \\
\hline 37 & - & + & - & + \\
\hline 45 & - & - & - & - \\
\hline
\end{tabular}

isolates were positive for peptonization of milk and decomposition of calcium malate, and negative for gelatin liquefaction, hydrolysis of starch and reduction of nitrate. The optimum temperature for growth of all isolates was $20-25^{\circ} \mathrm{C}$.

\section{Chemotaxonomic characteristics}

The menaquinone composition, whole-cell sugar pattern, amino acid composition of the cell wall, phospholipid type and $\mathrm{G}+\mathrm{C}$ content of DNA are shown in
Table 4. The major menaquinone was MK-9 $\left(\mathrm{H}_{6}\right)$, and small amounts of MK-9 $\left(\mathrm{H}_{4}\right)$ and MK-9 $\left(\mathrm{H}_{8}\right)$ were also present. The cell walls contained meso-diaminopimelic acid, glycine, glutamic acid and alanine, indicating that the wall chemotype of the isolates is II according to Lechevalier \& Lechevalier (1970), and the type of peptidoglycan is suggested to be Al $\gamma$ according to Schleifer \& Kandler (1972). Isolates contained large amounts of acofriose (3- $O$-methylrhamnose) and glucose in the whole cells. As diagnostic phospholipids, phosphatidylethanolamine was detected, but phos- 
Table 4. Chemotaxonomic characteristics of the strains studied

\begin{tabular}{|c|c|c|c|c|}
\hline \multirow[t]{2}{*}{ Characteristic } & \multicolumn{4}{|c|}{ Strain } \\
\hline & YU $629-21^{\mathrm{T}}$ & YU $636-3^{T}$ & YU 655-31 & YU 656-31 \\
\hline \multicolumn{5}{|l|}{ Major menaquinone (\%) } \\
\hline MK-9 $\left(\mathrm{H}_{4}\right)$ & 11 & 13 & 8 & 13 \\
\hline MK-9( $\left(\mathrm{H}_{6}\right)$ & 54 & 53 & 45 & 56 \\
\hline MK-9 $\left(\mathrm{H}_{8}\right)$ & 35 & 34 & 47 & 31 \\
\hline \multicolumn{5}{|l|}{$\begin{array}{l}\text { Sugar composition of whole } \\
\text { cells }(\%) \text { : }\end{array}$} \\
\hline Glucosamine & 47 & 46 & 41 & 30 \\
\hline Acofriose & 11 & 14 & 9 & 13 \\
\hline Rhamnose & & 4 & 1 & \\
\hline Ribose & 2 & & & \\
\hline Mannose & 4 & 4 & 2 & 2 \\
\hline Arabinose & 5 & 7 & 3 & 4 \\
\hline Galactose & 5 & 7 & 4 & 5 \\
\hline Xylose & 4 & 4 & & \\
\hline Glucose & 22 & 15 & 40 & 45 \\
\hline \multicolumn{5}{|l|}{$\begin{array}{l}\text { Amino acid composition of } \\
\text { peptidoglycan (molar ratio)* }\end{array}$} \\
\hline Glutamic acid & 1.00 & 1.00 & 1.00 & $1 \cdot 00$ \\
\hline Glycine & $2 \cdot 15$ & $2 \cdot 51$ & 1.85 & 2.59 \\
\hline Alanine & $0 \cdot 90$ & 0.84 & $0 \cdot 81$ & 0.97 \\
\hline meso-Diaminopimelic acid & 0.78 & 0.86 & 0.43 & 0.71 \\
\hline \multicolumn{5}{|l|}{ Phospholipid composition $†$} \\
\hline Phosphatidylglycerol & - & - & - & - \\
\hline $\begin{array}{l}\text { Unidentified phospholipid } \\
\text { including glucosamine }\end{array}$ & - & - & - & - \\
\hline Phosphatidylcholine & - & - & - & - \\
\hline Phosphatidylethanolamine & + & + & + & + \\
\hline Phospholipid type & PII & PII & PII & PII \\
\hline Mycolic acid $\dagger$ & - & - & - & - \\
\hline Glycolyl test & Acetyl & Acetyl & Acetyl & Acetyl \\
\hline DNA G + C content $(\mathrm{mol} \%)$ & $70 \cdot 1$ & $70 \cdot 3$ & $70 \cdot 2$ & $70 \cdot 4$ \\
\hline
\end{tabular}

* Calculated by defining the amount of glutamic acid as 1.00 .

$\dagger+$, Present; - absent.

Table 5. Percentage cellular fatty acid composition of the strains studied

\begin{tabular}{|c|c|c|c|c|c|c|c|c|c|c|c|c|}
\hline \multirow[t]{2}{*}{ Strain } & \multicolumn{2}{|c|}{ Iso-branched } & \multirow{2}{*}{$\begin{array}{c}\begin{array}{c}\text { Anteiso- } \\
\text { branched }\end{array} \\
\mathrm{C}_{17: 0}\end{array}$} & \multicolumn{5}{|c|}{ Saturated } & \multicolumn{3}{|c|}{ Unsaturated } & \multirow[t]{2}{*}{ Unidentified } \\
\hline & $C_{16: 0}$ & $C_{17: 0}$ & & $C_{15: 0}$ & $C_{16: 0}$ & $C_{17: 0}$ & $C_{18: 0}$ & $C_{19: 0}$ & $C_{17: 1}$ & $C_{18: 1}$ & $C_{19: 1}$ & \\
\hline YU $629-21^{\mathrm{T}}$ & $24 \cdot 0$ & $0 \cdot 9$ & $4 \cdot 4$ & 1.8 & $10 \cdot 1$ & $13 \cdot 3$ & 6.0 & $1 \cdot 1$ & $14 \cdot 1$ & $22 \cdot 3$ & $1 \cdot 4$ & 0.6 \\
\hline YU $636-3^{T}$ & $50 \cdot 1$ & 1.6 & $4 \cdot 8$ & 1.0 & $5 \cdot 5$ & $6 \cdot 1$ & 1.8 & & $11 \cdot 1$ & $12 \cdot 7$ & 1.8 & $3 \cdot 5$ \\
\hline YU 655-31 & $41 \cdot 6$ & 1.0 & 3.9 & 1.7 & $6 \cdot 7$ & $9 \cdot 2$ & $2 \cdot 4$ & 0.5 & $16 \cdot 3$ & $13 \cdot 6$ & $0 \cdot 8$ & $2 \cdot 4$ \\
\hline YU 656-31 & $50 \cdot 7$ & $1 \cdot 3$ & $3 \cdot 7$ & $1 \cdot 2$ & $5 \cdot 0$ & 6.5 & 1.6 & & $16 \cdot 7$ & $11 \cdot 1$ & $2 \cdot 3$ & \\
\hline
\end{tabular}

phatidylglycerol, phosphatidylcholine and unidentified phospholipid including glucosamine were not detected. This pattern corresponds to phospholipid type II (Lechevalier et al., 1977). The $\mathrm{G}+\mathrm{C}$ contents of
DNAs were $70 \mathrm{~mol} \%$. Mycolic acid was absent. The fatty acids are shown in Table 5 . The major cellular fatty acids of strain YU 629-21 ${ }^{\mathrm{T}}$ were iso- $\mathrm{C}_{16: 0}, \mathrm{C}_{18: 1}$, $C_{17: 1}, C_{17: 0}$ and $C_{16: 0}$, and those of strains YU $636-3^{\mathrm{t}}$, 
Table 6. Levels of DNA relatedness among the strains studied

\begin{tabular}{|lcccc|}
\hline Strain & \multicolumn{3}{c|}{ Percentage of DNA complementary to labelled DNA from strain: } \\
\cline { 2 - 5 } & YU 629-21 & YU 636-3 & YU 655-31 & YU 656-31 \\
\hline YU 629-21 & & & & \\
YU 636-3 & 100 & 44 & 45 & 42 \\
YU 655-31 & 38 & 100 & 40 & 48 \\
YU 656-31 & 49 & 47 & 100 & 72 \\
\end{tabular}

YU 655-31 and YU 656-31 were iso- $\mathrm{C}_{16: 0}, \mathrm{C}_{18: 1}$ and $\mathrm{C}_{17: 1}$. Both cellular fatty acid patterns correspond to fatty acid type 2a (Kroppenstedt, 1985). The acyl-type of cell wall polysaccharides was acetyl.

\section{DNA-DNA hybridization}

The results of DNA-DNA hybridization studies indicated that the four strains were divided into three DNA homologous groups: strain YU $629-21^{\mathrm{T}}$, strain YU 636- $3^{\mathrm{T}}$ and strains YU 655-31 and YU 656-31 (Table 6). Strains YU 655-31 and YU 656-31 exhibited species level DNA relatedness (i.e. $>70 \%$ relatedness). DNA reassociation between strains YU 629$21^{\mathrm{T}}$, YU 636- $3^{\mathrm{T}}$ and $\mathrm{YU}$ 655-31 ranged from 38 to $57 \%$.

\section{Phylogenetic position}

16S rDNA sequences were determined for YU 629$21^{\mathrm{T}}$ [positions 28-1524, according to the Escherichia coli numbering system of Brosius et al. (1978); total 1463 bases], YU 636-3 ${ }^{\mathrm{T}}$ (positions 28-1513; total 1459 bases), YU 655-31 (positions 28-1524; total 1462 bases) and YU 656-31 (positions 28-1524; total 1462 bases). The positions at which secondary structures varied between strains and the positions at which sequences were not determined in some reference organisms were excluded from the analysis. For phylogenetic analysis, the total number of nucleotides compared was 1119 after elimination of all sites which were not determined in any sequence. The phylogenetic tree obtained by applying the neighbour-joining method to $K_{\text {nuc }}$ values is depicted in Fig. 3. 16S rDNA analysis revealed that the isolates represent a line of descent distinct from previously described actinomycetes (Fig. 3), and similarity values between isolates and other organisms were under $93.8 \%$. The isolates are the closest neighbours with the members of suborder Frankineae (Stackebrandt et al., 1997) which consists of the genera Sporichthya (Lechevalier et al., 1968; similarity values 92.7-93.8\%), Frankia (Lechevalier \& Lechevalier, 1989; similarity values 92.9-93.7\%), Geodermatophilus (Luedemann, 1968; similarity values $92.2-93.3 \%$ ), Acidothermus (Mohagheghi et al., 1986; similarity values 91.1$92.0 \%$ ), Blastococcus (Ahrens \& Moll, 1970; similarity values $91.0-92.2 \%$ ) and Microsphaera (Yoshimi et al., 1996; similarity values $92 \cdot 2-93 \cdot 0 \%$ ).

\section{DISCUSSION}

The strains YU 629-21 ${ }^{\mathrm{T}}$, YU 636-3 $3^{\mathrm{T}}$, YU 655-31 and YU 656-31 developed sporangia and mycelia. Characteristics of the isolates and related genera forming sporangia with motile spores are shown in Table 7. The genera Spirillospora, Planobispora, Planomonospora and Planotetraspora have meso-diaminopimelic acid in the cell wall (cell wall type III) and madurose as a characteristic whole-cell sugar (sugar pattern B). The genus Streptoalloteichus has cell wall type III. However, the isolates described here have glycine and mesodiaminopimelic acid in the cell wall (cell wall type II) and acofriose (3-O-methylrhamnose) as the characteristic whole-cell sugar. The known actinomycetes with cell wall type II are members of the family Micromonosporaceae and the genus Glycomyces. Among the genera with wall chemotype II, Actinoplanes, Dactylosporangium and Pilimelia have sporangia and motile elements. However, the isolates are distinguished from these genera in their morphological characteristics and in having acofriose as a whole-cell sugar and the acyl-type of peptidoglycan. Isolates can also be distinguished from Dactylosporangium and Pilimelia by the menaquinone system. Members of the genus Catellatospora (Asano \& Kawamoto, 1986) are known to have acofriose as the whole-cell sugar. However, this organism does not form a sporangium and motile spores, and has a different phylogenetic position to the isolates. Other actinomycetes with chemotype II, Spirilliplanes and Glycomyces, are distinguishable from the isolates in morphology, acyl type and menaquinone composition. Thus in their morphological and chemotaxonomic characteristics, the isolates are distinct from the known actinomycetes with chemotype II and other previously described organisms (Table 7).

The phylogenetic tree indicates that isolates are distinct from all actinomycetes whose sequences are available in databases. The isolates are phylogenetically most closely related to members of the genera Sporichthya (Lechevalier et al., 1968), Frankia (Lechevalier \& Lechevalier, 1989), Geodermatophilus (Luedemann, 1968), Acidothermus (Mohagheghi et al., 1986), Blastococcus (Ahrens \& Moll, 1970) and Microsphaera (Yoshimi et al., 1996). Recently, these organisms have been assigned to the suborder Frankineae (Stackebrandt et al., 1997). Members of this suborder have various morphological and chemotaxonomic charac- 


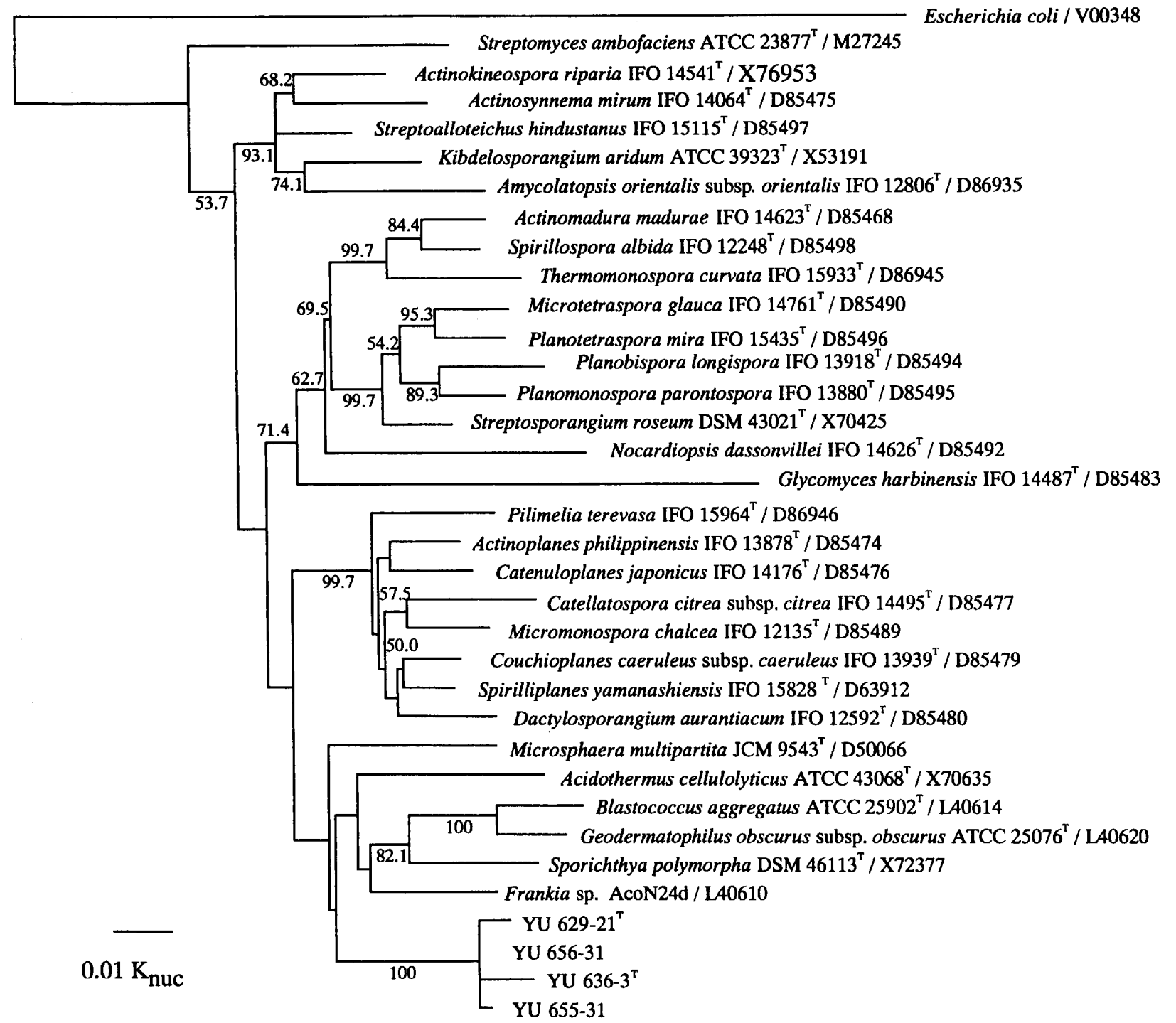

Fig. 3. Phylogenetic tree derived from 165 rRNA sequences of actinomycetes. $E$. coli was used as the outgroup. Bar, $0 \cdot 01$ $K_{\text {nuc }}$ in nucleotide sequences. The numbers on the branches are confidence limits (expressed as percentages) estimated from a bootstrap analysis with 1000 replicates (only percentages above $50 \%$ are indicated).

teristics which are distinct from those of the isolates described here. The genus Sporichthya shows motility and has LL-diaminopimelic acid as diamino acid in the cell wall. The genus Geodermatophilus develops zoospores and rudimentary mycelia, but does not produce aerial mycelium. The genus Frankia does not form aerial mycelium or zoospores.

The results of DNA-DNA hybridization of the four strains revealed that they were genetically divided into three groups. Strain YU 629-21 ${ }^{\mathrm{T}}$ was distinguished from other strains by the cellular fatty acid pattern; however, strains YU 636-3 ${ }^{\mathrm{T}}$ and YU 655-31 and YU 656-31 did not have any diagnostic phenotypic differences. Phenotypic characteristics may be reflected by only a few genes. Diagnostic differences between the last three strains may be found by further study.

On the basis of morphological, physiological, chemotaxonomic and phylogenetic criteria, strains YU 629$21^{\mathrm{T}}$, YU 636-3 ${ }^{\mathrm{T}}$, YU 655-31 and YU 656-31 are readily distinguishable from the motile actinomycetes mentioned above and warrant the formation of a new taxon. Therefore, we propose that strains YU 629$21^{\mathrm{T}}$, YU 636-3 ${ }^{\mathrm{T}}$, YU 655-31 and YU 656-31 be classified in a new genus, Cryptosporangium gen. nov., with the type species Cryptosporangium arvum sp. nov. (type strain IFO $15965^{\mathrm{T}}$ ).

From the phylogenetic analysis, the genus Cryptosporangium can be considered to belong to the sub- 
Table 7. Differential characteristics of the genus Cryptosporangium and related genera

\begin{tabular}{|c|c|c|c|c|c|c|c|c|c|}
\hline Genus & $\begin{array}{c}\text { DNA } \mathbf{G}+\mathbf{C} \text { content } \\
(\mathrm{mol} \%)\end{array}$ & $\begin{array}{l}\text { Motility of } \\
\text { spore* }\end{array}$ & $\begin{array}{l}\text { Sporangium } \\
\text { formation* }\end{array}$ & $\begin{array}{c}\text { Fatty acid } \\
\text { type } \dagger\end{array}$ & Glycolate & $\begin{array}{c}\text { Cell wall } \\
\text { type }\end{array}$ & Major menaquinones & $\begin{array}{c}\text { Phospholipid } \\
\text { type } \$\end{array}$ & $\begin{array}{l}\text { Characteristic sugar in } \\
\text { whole cells } \Phi\end{array}$ \\
\hline Cryptosporangium & 70 & + & + & $2 \mathrm{a}$ & Acetyl & II & MK-9(- $\left.\mathrm{H}_{6}\right)$ & PII & Aco \\
\hline Actinoplanes & $72-73$ & + & + & $2 d$ & Glycoly1 & II & MK-9( $\left.\mathrm{H}_{4}\right), 10\left(\mathrm{H}_{4}\right)$ & PII & Ara, Xyl \\
\hline Dactylosporangium & $72-73$ & + & + & $3 b$ & Glycolyl & II & MK-9( $\left.\mathrm{H}_{4}, \mathbf{H}_{6}, \mathrm{H}_{8}\right)$ & PII & Ara, Xyl \\
\hline Pilimelia & ND & + & + & $2 d$ & Glycolyl & II & MK- $9\left(\mathrm{H}_{2}, \mathrm{H}_{4}\right)$ & PII & Ara, Xyl \\
\hline Spirillospora & $69-71$ & + & + & $3 \mathrm{a}$ & ND & III & MK- $9\left(\mathrm{H}_{4}, \mathrm{H}_{6}\right)$ & PI & $\mathrm{Mad}$ \\
\hline Streptoalloteichus & ND & + & + & ND & Acetyl & III & MK- $9\left(\mathrm{H}_{8}\right), 10\left(\mathrm{H}_{6}\right)$ & PII & Gal, Man \\
\hline Planomonospora & 72 & + & + & $3 \mathrm{c}$ & Acetyl & III & MK- $9\left(\mathrm{H}_{2}, \mathrm{H}_{4}\right)$ & PIV & Mad \\
\hline Planobispora & $70-71$ & + & + & $3 \mathrm{c}$ & Acetyl & III & MK- $9\left(\mathrm{H}_{2}\right)$ & PIV & Mad \\
\hline Planotetraspora & ND & + & + & ND & $\mathrm{ND}$ & III & $\mathrm{ND}$ & ND & Ara, Xyl \\
\hline Micromonospora & $71-73$ & - & - & $3 b$ & Glycolyl & II & MK-10( $\left.\mathrm{H}_{4}, \mathrm{H}_{6}\right) / 9\left(\mathrm{H}_{4}, \mathrm{H}_{6}\right)$ & PII & Ara, Xyl \\
\hline Catellatospora & $71-72$ & - & - & ND & Glycolyl & II & MK-10( $\left.\mathrm{H}_{8}, \mathrm{H}_{6}\right) / 9\left(\mathrm{H}_{4}, \mathrm{H}_{8}\right)$ & PII & Ara, Xyl \\
\hline Spirilliplanes & 69 & + & - & $2 d$ & Glycolyl & II & MK- $10\left(\mathrm{H}_{4}\right)$ & PII & Xyl, 3-O-M-Man \\
\hline Catenuloplanes & $71-73$ & + & - & $2 c$ & Glycolyl & VI & MK-9( $\left.\mathrm{H}_{8}\right), 10\left(\mathrm{H}_{8}\right)$ & PIII & Xyl \\
\hline Couchioplanes & $70-72$ & + & - & $2 c$ & Glycolyl & VI & MK- $9\left(\mathrm{H}_{4}\right)$ & PII & Ara, Xyl \\
\hline Glycomyces & $71-73$ & - & - & $2 \mathrm{c}$ & Glycolyl & II & MK-9( $\left.\mathrm{H}_{4}\right), 10\left(\mathrm{H}_{2}, \mathrm{H}_{4}\right)$ & PI & Ara, Xyl \\
\hline
\end{tabular}

ND, Not determined.

$*+$, Present; - , absent.

$\dagger$ According to the classification of Kroppenstedt (1985).

$\ddagger$ According to the classification of Lechevalier \& Lechevalier (1970).

$\S$ According to the classification of Lechevalier et al. (1977).

I Aco, acofriose; Ara, arabinose; Xyl, xylose; Mad, madurose; Gal, galactose; Man, mannose; 3-O-M-Man, 3-O-methylmannose.

order Frankineae. Further study will be needed to clarify the relationship of the genus Cryptosporangium with other members of the suborder Frankineae.

\section{Description of Cryptosporangium gen. nov.}

Cryptosporangium [cryp'to.spo.ran'gi.um. Gr. adj. kryptos hidden; Gr. n. spora a seed, spore; Gr. n. argeion vessel; M.L. neut. n. Cryptosporangium an organism with spore-containing vessels (sporangia) covered or hidden by mycelium].

Gram-positive, non-acid-fast, aerobic organisms with branching hyphae. Non-fragmentary substrate mycelia are present. The sporangia and aerial mycelia aggregate, and sporangiospores show motility when they are suspended in water. Morphology of a 14-d-old culture grown on inorganic salts/starch agar shows the presence of aerial mycelia. Strictly aerobic. Good growth occurs at $20-25^{\circ} \mathrm{C}$. The organism shows good growth on oatmeal agar, inorganic salts/starch agar and peptone/yeast extract iron agar. In general, the vegetative mycelia are yellow to orange and the aerial mycelia are white. Cell walls contain glutamic acid, glucosamine, glycine, alanine and meso-diaminopimelic acid. Wall chemotype is II according to Lechevalier \& Lechevalier (1970), and the peptidoglycan type is suggested to be Al $\gamma$ according to Schleifer \& Kandler (1972). Glucose and acofriose are detected as whole-cell sugars. As major cellular fatty acids, $C_{17: 1}$, $\mathrm{C}_{18: 1}$ and iso- $\mathrm{C}_{16: 0}$ are present. The $\mathrm{G}+\mathrm{C}$ content of DNA is $70 \mathrm{~mol} \%$. The major menaquinone is MK$9\left(\mathrm{H}_{6}\right)$, and small amounts of $\mathrm{MK}-9\left(\mathrm{H}_{4}\right)$ and $9\left(\mathrm{H}_{8}\right)$ are also present. Phosphatidylethanolamine and phosphatidylinositol are present as diagnostic phospholipids (phospholipid pattern type PII). The acyl-type of cell wall polysaccharides is acetyl. Habitat: soil. The type species is Cryptosporangium arvum.

\section{Description of Cryptosporangium arvum sp. nov.}

Cryptosporangium arvum (ar.vum. L. $\mathbf{n}$. arvum arable land, pertaining to isolate from arable land).

Morphological, chemotaxonomic and general characteristics are as given above for the genus. Pale reddishbrown soluble pigment is produced on tyrosine agar (ISP medium 7). Gelatin liquefaction is negative. Does not hydrolyse starch. Decomposes calcium malate. Coagulates milk. Xylose, glucose, inositol, raffinose, rhamnose, mannitol, sucrose, arabinose, glycerol, lactose, maltose and mannose are utilized, but sorbitol and inulin are not. No growth at $37^{\circ} \mathrm{C}$. As major cellular fatty acids, iso- $\mathrm{C}_{16: 0}, \mathrm{C}_{18: 1}, \mathrm{C}_{17: 1}, \mathrm{C}_{17: 0}$ and $C_{16: 0}$ are present. The $G+C$ content of DNA is 70 mol\%. Habitat: cultivated soil. The type strain is YU $629-21^{\mathrm{T}}\left(=\right.$ IFO $\left.15965^{\mathrm{T}}\right)$.

\section{Description of Cryptosporangium japonicum sp. nov.}

Cryptosporangium japonicum (ja.po'ni.cum. M.L. masc. adj. japonicum pertaining to Japan where the organisms were isolated).

Morphological, chemotaxonomic and general characteristics are as given above for the genus. Pale reddish brownish soluble pigment is produced on tyrosine agar (ISP medium 7). Gelatin liquefaction is negative. Does not hydrolyse starch. Decomposes calcium malate. Coagulates milk. Xylose, glucose, inositol, raffinose, rhamnose, mannitol, sucrose, fructose, arabinose, lactose, galactose, maltose and mannose are utilized, 
but sorbitol and inulin are not. Grows at $37^{\circ} \mathrm{C}$. The $\mathrm{G}+\mathrm{C}$ content of DNA is $70 \mathrm{~mol} \%$. Habitat: cultivated soil. The type strain is YU $636-3^{\mathrm{T}}(=\mathrm{IFO}$ $\left.15966^{\mathrm{T}}\right)$.

\section{ACKNOWLEDGEMENTS}

This research was supported in part by a grant from the Waksman Foundation of Japan Inc. We thank Dr Akira Yokota (The University of Tokyo) for his generous gift of acofriose.

\section{REFERENCES}

Ahrens, R. \& Moll, G. (1970). Ein neues knospendes Bakterium aus der Ostsee. Arch Mikrobiol 70, 243-265.

Asano, K. \& Kawamoto, I. (1986). Catellatospora, a new genus of the Actinomycetales. Int J Syst Bacteriol 36, 512-517.

Brosius, J., Palmer, J. L., Kennedy, J. P. \& Noller, H. F. (1978). Complete nucleotide sequence of a $16 \mathrm{~S}$ ribosomal RNA gene from Escherichia coli. Proc Natl Acad Sci USA 75, 4801-4805.

Couch, J. N. (1950). Actinoplanes a new genus of the Actinomycetales. J Elisha Mitchell Sci Soc 66, 87-92.

Couch, J. N. (1963). Some new genera and species of the Actinoplanaceae. J Elisha Mitchell Sci Soc 79, 53-70.

Ezaki, T., Hashimoto, Y. \& Yabuuchi, E. (1989). Fluorometric deoxyribonucleic acid-deoxyribonucleic acid hybridization in microdilution wells as an alternative to membrane filter hybridization in which radioisotopes are used to determine genetic relatedness among bacterial strains. Int $J$ Syst Bacteriol 39, 224-229.

Felsenstein, J. (1985). Confidence limits on phylogenies: an approach using the bootstrap. Evolution 39, 783-791.

Gordon, M. A. (1964). The genus Dermatophilus. J Bacteriol 88, 509-522.

Hayakawa, M. \& Nonomura, H. (1987). Humic acid-vitamin agar, a new medium for selective isolation of soil actinomycetes. $J$ Ferment Technol 65, 501-509.

Hayakawa, M., Tamura, T. \& Nonomura, H. (1992). Selective isolation of Actinoplanes and Dactylosporangium from soil by using $\gamma$-collidine as the chemoattractant. $J$ Ferment Bioeng $\mathbf{7 2}$, 426-432.

Kane, W. D. (1966). A new genus of Actinoplanaceae, Pilimelia, with a description of two species, Pilimelia terevasa and Pilimelia anulata. J Elisha Mitchell Sci Soc 82, 220-230.

Kimura, M. (1980). A simple method for estimating evolutionary rates of base substitutions through comparative studies of nucleotide sequences. $J$ Mol Evol 16, 111-120.

Kroppenstedt, R. M. (1985). Fatty acid and menaquinone analysis of actinomycetes and related organisms. In Chemical Methods in Bacterial Systematics, pp. 173-199. Edited by M. Goodfellow \& D. E. Minnikin. London: Academic Press.

Labeda, D. P., Testa, R. T., Lechevalier, M. P. \& Lechevalier, H. A. (1985). Glycomyces, a new genus of the Actinomycetales. Int $J$ Syst Bacteriol 35, 417-421.

Lechevalier, M. P. \& Lechevalier, H. A. (1970). Chemical composition as a criterion in the classification of aerobic actinomycetes. Int $J$ Syst Bacteriol 20, 435-443.

Lechevalier, M. P. \& Lechevalier, H. A. (1989). Genus Frankia Brunchorst $1886,174^{\mathrm{AL}}$. In Bergey's Manual of Systematic Bacteriology, vol. 4, pp. 2410-2417. Edited by S. T. Williams, M. E. Sharpe \& J. G. Holt. Baltimore: Williams \& Wilkins.
Lechevalier, M. P., Lechevalier, H. A. \& Holbert, P. E. (1968). Sporichthya, un nouveau genre de Streptomycetaceae. Ann Inst Pasteur 114, 277-286.

Lechevalier, M. P., DeBievre, C. \& Lechevalier, H. A. (1977). Chemotaxonomy of aerobic actinomycetes: phospholipid composition. Biochem Syst Ecol 5, 249-260.

Luedemann, G. M. (1968). Geodermatophilus, a new genus of the Dermatophilaceae (Actinomycetales). J Bacteriol 96, 1848-1858.

Mesbah, M., Premachandran, U. \& Whitman, W. B. (1989). Precise measurement of the $\mathrm{G}+\mathrm{C}$ content of deoxyribonucleic acid by high-performance liquid chromatography. Int J Syst Bacteriol 39, 159-167.

Mohagheghi, A., Grohmann, K., Himmel, M., Leighton, L. \& Updegraff, D. M. (1986). Isolation and characterization of Acidothermus cellulolyticus gen. nov., sp. nov., a new genus of thermophilic, acidophilic, cellulolytic bacteria. Int $J$ Syst Bacteriol 36, 435-443.

Pernodet, J.-L., Borccard, F., Alegre, M.-T., Gargnat, J. \& Guérineau, M. (1989). Organization and nucleotide sequence analysis of ribosomal RNA gene cluster from Streptomyces ambofaciens. Gene 79, 33-46.

Rayner, R. W. (1970). A Mycological Colour Chart. Commonwealth Mycological Institute, Kew: Surrey \& British Mycological Society.

Runmao, H., Guizhen, W. \& Junying, L. (1993). A new genus of actinomycetes, Planotetraspora gen. nov. Int $J$ Syst Bacteriol 43, 468-470.

Saiki, R. K., Gelfand, D. H., Stoffe, S., Scharf, S. J., Higuchi, R., Horn, G. T., Mullis, K. B. \& Erlich, A. (1988). Primer-directed enzymatic amplification of DNA with a thermostable DNA polymerase. Science 239, 487-491.

Saito, H. \& Miura, K. (1963). Preparation of transforming deoxyribonucleic acid by phenol treatment. Biochim Biophys Acta 72, 619-629.

Saitou, N. \& Nei, M. (1987). The neighbor-joining method: a new method for reconstructing phylogenetic trees. Mol Biol Evol 4, 406-425.

Schleifer, K. H. \& Kandler, O. (1972). Peptidoglycan types of bacterial cell walls and their taxonomic implications. Bacteriol Rev 36, 407-477.

Shirling, E. B. \& Gottlieb, D. (1966). Methods for characterization of Streptomyces species. Int J Syst Bacteriol 16, 313-340.

Stackebrandt, E., Rainey, F. A. \& Ward-Rainey, N. L. (1997). Proposal for a new hierarchic classification system, Actinobacteria classis nov. Int J Syst Bacteriol 47, 479-491.

Tamura, T., Nakagaito, Y., Nishii, T., Hasegawa, T., Stackebrandt, E. \& Yokota, A. (1994). A new genus of the order Actinomycetales, Couchioplanes gen. nov., with descriptions of Couchioplanes caeruleus (Horan and Brodsky 1986) comb. nov. and Couchioplanes caeruleus subsp. azureus subsp. nov. Int J Syst Bacteriol 44, 193-203.

Thiemann, J. E. \& Beretta, G. (1968). A new genus of the Actinoplanaceae: Planobispora, gen. nov. Arch Mikrobiol 62, 157-166.

Thiemann, J. E., Pagani, H. \& Beretta, G. (1967a). A new genus of the Actinoplanaceae: Planomonospora, gen. nov. Giorn Microbiol 15, 27-38.

Thiemann, J. E., Pagani, H. \& Beretta, G. (1967b). A new genus of the Actinoplanaceae: Dactylosporangium, gen. nov. Arch Microbiol 58, 42-52. 
Tomita, K., Uenoyama, Y., Numata, K., Sasahira, T., Hoshino, Y., Fugisawa, K., Tsukiura, H. \& Kawaguchi, H. (1978). Streptoalloteichus, a new genus of the family Actinoplanaceae. $J$ Antibiot 31, 497-510.

Yokota, A., Tamura, T., Hasegawa, T. \& Huang, L. H. (1993). Catenuloplanes japonicus gen. nov., sp. nov., nom. rev., a new genus of the order Actinomycetales. Int $J$ Syst Bacteriol 43, 805-812.

Yoshimi, Y., Hiraishi, A. \& Nakamura, K. (1996). Isolation and characterization of Microsphaera multipartita gen. nov., sp. nov., a polysaccharide-accumulating gram-positive bacterium from activated sludge. Int $J$ Syst Bacteriol 46, 519-525. 